Printing Office. 45 cents). Rather less than one per cent of the total continental area of the United States comes under the care of the National Park System. In 1944 several small additions were made, but the only one of considerable size was in Texas, and the one of most interest was the home of F. D. Roosevelt, which was classed as a historic site. There were war-time difficulties to be faced. Two parks in particular were threatened by economic needs. A threat to the Sitka pines in the Olympic National Park, which were wanted for aircraft production, was averted by supplies from British Columbia and by the increased production of aluminium. Red spruce and hemlock of the Great Smoky Mountain Park were spared by alternative supplies for papermaking being found. Drought conditions in the spring of 1944 raised a demand for the Californian parks to be opened to cattle grazing, but the Parks Committee, after a full inquiry, did not feel justified in granting the request. The demand, however, is to be renewed. In spite of war conditions, the national parks have remained open to visitors and have beon much frequented.

\section{Map of British Isles}

A colouren map of the British Isles, designed to illustrate several aspects of their geography, has been published as a reprint from a Polish volume compiled under the editorship of Dr. Z. Holub-Pacewicz (Glasgow : Ksiáżnica Polska). A brief commentary and the legend, both in English, explain the chief features. The small scale, 1 to $3,000,000$, limits the amount of detail and necessitates many generalizations. Perhaps the most noteworthy feature is the analysis of the structure and relief of the coast-line. Eight different types of coast-line are indicated by different colours and symbols. Surface relief is shown by layer colouring, and a few names are given, but, except for the scarps of the south-east, there are no indications of structure. The more important towns are shown with indications of size, but there seems to be a little confusion in the use of the term 'conurbation'. Lost towns in plenty are indicated off the East Riding coast and a few off the Lancashire coast, but none elsewhere. The chief railway lines are marked. The notes accompanying the translated commentary include references to suitable reading, so that the book should help to achieve its object of giving Poles some idea of Great Britain.

Protection of Timber against Powderpost Beetles

ALL who have had anything to do with timber in tropical or semi-tropical regions will have become acquainted with the work of certain boring beetles, or powderpost beetles as they have been termed, of the family Bostrychidæ; posts and sawn timber of most broad-leaved trees are liable to severe damage. The chief damage is done by the larvæ feeding on the sap wood, as is well known: Research and experiments have been carried out in more than one part of the world, with the view of discovering some cheap and practicable method of protecting wood from this type of pest. In leaflet No. 69 (Entomology) of the Forest Research Institute, Dehra Dun, preliminary tests of two methods of protecting timber are dealt with. They are intended to give temporary protection when more standard treatment such as impregnation with preservatives cannot be applied because of lack of plant or material. A mixture of creosote and fuel oil, applied externally, definitely prevents attack for at least nine months and prob- ably longer. A coating of lime gave complete protection over a period of three months when liability to attack was most serious. It is expected that, provided the coating is kept intact, protection will be permanent. In each case, it is emphasized that treatment must be applied within a short period of cutting or sawing.

\section{Fluorescence Microscopy of Tubercle Bacilli}

Aparato Respiratorio $Y$ Tuberculosis (9, No. 4, Oct.-Dec. 1944, published in Santiago De Chile) has a paper with the title "La Microscopia Fluorescente En La Investigacion Del Bacilo Tuberculoso" contrib. uted by Dr. B. Juricic, Sr. Nicolás Vuskovic, Drs. Gastón, González, Hernán Durán, and Hipólito Vergara. In this they describe the results of their investigation of 5,044 cases in which samples of expectoration and gastric contents over a period of a year and a half were examined by the fluorescence microscope. The accessories utilized for transforming the microscope into a fluorescence type were those manufactured by the Spencer Lens Co., Buffalo, and consist of an electric bulb of low voltage and high amperage, provided with a blue-violet filter, and in addition, of an aluminized mirror with a yellow filter. for the eyepiece. A monocular microscope was found more satisfactory than a binocular, the number of prisms in the latter considerably diminishing the fluorescence. The results are shown in two tables and a third supplies comparative figures for the Ziehl-Neelsen method. The advantages of the fluorescence method are obvious from this comparison; 52 per cent greater positive results being obtained than with the Ziehl-Neelsen method. In addition, less time is spent in staining the specimens, there is greater rapidity in the examination, and the use of oil immersion is avoided. It is claimed that the fluorescence microscope has a brilliant future before it and that its efficiency is susceptible of great improvement in various ways.

\section{An Electrical Moisture Meter}

In a paper read on April 20 before the Institution of Electrical Engineers in London, Dr. L. Hartshorn and Mr. W. Wilson first outline the purpose which moisture meters are intended to serve, and the various types which have already been described, and then describe the development and construction of a new type of meter that has already been put to good use in several industries. A constant alternating voltage is applied to a sample of the material contained in a small vessel, which may be regarded as a fixed air condenser, or in some instances as a conductivity cell. The current passing through the material is measured by means of a sensitive thermionic ammeter of special construction, which can be adjusted to read the capacitance current, proportional to the dielectric constant of the material; the conductance current, proportional to its A.C. conductivity; or some function of both these currents. The current selected is that which shows the most favourable variation with moisture content. The use of the meter for testing seeds and grain, dried foods and flax straw is discussed, and typical results are given, together with a brief outline of other applications.

\section{Determination of Time Corrections}

THF Astronomical Institute of the Academy of Sciences of the U.S.S.R. has issued an "Ephemerides for the Determination of Time Corrections by Equal 